\title{
Impact of Methimazole Treatment on Magnesium Concentration and Lymphocytes Activation in Adolescents with Graves' Disease
}

\author{
Maria Klatka • Ewelina Grywalska • Malgorzata Partyka • \\ Malgorzata Charytanowicz $\cdot$ Jacek Rolinski
}

Received: 19 April 2013 / Accepted: 29 April 2013 /Published online: 11 May 2013

(C) The Author(s) 2013. This article is published with open access at Springerlink.com

\begin{abstract}
The aim of this research was to assess plasma magnesium $(\mathrm{Mg})$ concentration, the frequencies of activated $\mathrm{T}$ CD4+ and T CD8+ lymphocytes and B lymphocytes in adolescents with hyperthyroidism due to Graves' disease (GD), and to assess changes in the above-mentioned parameters during methimazole (MMI) treatment. The frequencies of activated $\mathrm{T}$ and $\mathrm{B}$ cells were measured by flow cytometry method and plasma $\mathrm{Mg}$ concentration was determined by spectrophotometry method in 60 adolescents at the time of GD diagnosis and after receiving the normalisation of the thyroid hormones levels. The control group consisted of 20 healthy volunteers. We observed lower plasma $\mathrm{Mg}$ concentration, and higher frequencies of activated $\mathrm{T}$ and $\mathrm{B}$ lymphocytes in the study group before the treatment in comparison with healthy controls, and with study group in MMI-induced euthyreosis $(p<0.01)$.Statistically significant negative correlations between the percentages of activated $\mathrm{T} \mathrm{CD} 3+, \mathrm{T} C \mathrm{CD} 4+$, $\mathrm{T}$ CD8+ and B CD19+ lymphocytes, and plasma Mg concentration before the treatment were found $(r<-0.335, p<0.002)$. After the treatment no vital differences in plasma $\mathrm{Mg}$
\end{abstract}

M. Klatka

Department of Pediatric Endocrinology and Diabetology,

Medical University of Lublin, Lublin, Poland

E. Grywalska $(\bowtie) \cdot J$. Rolinski

Department of Clinical Immunology and Immunotherapy,

Medical University of Lublin, Chodzki 4a Street,

20-093 Lublin, Poland

e-mail: ewelina.grywalska@gmail.com

M. Partyka

Department of Jaw Orthopedics, Medical University of Lublin,

Lublin, Poland

M. Charytanowicz

Institute of Mathematics and Computer Science,

The John Paul II Catholic University, Lublin, Poland concentration, and in percentages of activated cells between GD patients and controls were found, except CD8+CD25+ cells $(p=0.03)$. The present study demonstrates that both activated $\mathrm{T}$ and $\mathrm{B}$ cells might play an important role in the pathogenesis of GD, and activation is related to Mg plasma level. The use of MMI in treatment of hyperthyroidism due to GD leads to decrease the frequencies of activated lymphocytes and normalisation of $\mathrm{Mg}$ levels.

Keywords Activation - Adolescents - Flow cytometry · Graves' disease $\cdot$ Lymphocytes $\cdot$ Magnesium

\section{Introduction}

Incidence of hyperthyroidism due to Graves' disease (GD) in Poland is estimated at about one case per 25,000 persons per year [1]. This disease occurs in all ages, but most often in middle age, children get sick more than ten times less likely than adults. In recent years, a trend towards an increase in the incidence of autoimmune hyperthyroidism in younger age groups is observed. Nowadays GD is the most common cause of hyperthyroidism in the paediatric population $[2,3]$.

The immune dysfunction in GD involves the generation of thyroid-stimulating hormone receptor autoantibodies that presumably arise consequent to interactions among various subsets of $\mathrm{T}$ and $\mathrm{B}$ cells. However, the immunological mechanisms of interactions between them that lead to the induction and regulation of this autoimmune disease are poorly defined [4]. Various studies emphasised that within the thyroid gland in GD are present clonally expanded T-cell populations $[5,6]$. The T-cell receptor complexes with an HLA molecule on the surface of an antigen-presenting cell when the appropriate antigenic peptide is present, such 
Table 1 Patient characteristics
Patient characteristics

Number of patients- $n$

Body weight $[\mathrm{kg}]$

Height $[\mathrm{cm}]$

Left thyroid lobe volume $[\mathrm{ml}]$

Right thyroid lobe volume [ml]

The volume of the thyroid gland $[\mathrm{ml}]$

TSI

Dosage of methimazole $[\mathrm{mg} / \mathrm{kg} / \mathrm{day}]$

Total daily dose of methimazole [mg/day]

Treatment duration of hyperthyroidism (from the diagnosis to methimazole-induced euthyrosis) [days] [days]

Relapse of hyperthyreosis after the treatment

Elapsed time between achieving euthyreosis and relapse [months]

Symptoms of hyperthyroidism at the time of diagnosis $n(\%)$

Hyperactivity

Nervousness

Emotional lability

Weight loss despite excellent appetite

Insomnia

Fatigue

Palpitations

Heat intolerance

Sweating

Menstrual irregularities

Muscle weakness

Eye symptoms - pain or diplopia

Signs of hyperthyroidism at the time of diagnosis $n(\%)$

Enlargement of the thyroid gland

Goiter class I

Goiter class II

Goiter class III
60

Median

48.92

(Min-max) (30-73)

Mean \pm SD

$157.29 \pm 8.96$

Median

158.9

(Min-max)

(140-180)

Mean \pm SD

$11.31 \pm 3.29$

Median

11.75

(Min-max)

(4.6-17.4)

Mean \pm SD

$10.64 \pm 3.19$

Median

10.73

(Min-max)

(3.67-18)

Mean \pm SD

$24.14 \pm 6.08$

Median

24.87

(Min-max)

$(10.47-35.5)$

Mean \pm SD

Median

$7.63 \pm 4.52$

(Min-max)

6.75

Mean \pm SD

Median

(1.8-22.4)

$0.50 \pm 0.05$

(Min-max)

0.50

Mean \pm SD

Median

(0.42-0.65)

(Min-max)

Mean \pm SD

Median

(Min-max)

Yes- $n(\%)$

No- $n(\%)$

Mean \pm SD

Median

(Min-max)

$53(88.33 \%)$

$60(100 \%)$

$47(78.33 \%)$

$50(83.33 \%)$

$44(73.33 \%)$

$46(76.67 \%)$

$45(75 \%)$

$40(66.67 \%)$

$38(63.33 \%)$

$16(26.67 \%)$

$20(33.33 \%)$

$17(28.33 \%)$

$54(90 \%)$

$24(40 \%)$

$25(41.67 \%)$

$5(8.33 \%)$
25

(10-40)

$42.98 \pm 4.30$

42.5

(36-50)

$22(36.67 \%)$

$38(63.33 \%)$

$23.36 \pm 8.25$

24.5

(6-35) 
Table 1 (continued)

\begin{tabular}{ll}
\hline Patient characteristics & \\
\hline Tachycardia & $58(96.67 \%)$ \\
Smooth sweaty skin & $50(83.33 \%)$ \\
Tremor or muscle fasciculations & $48(80 \%)$ \\
Eye findings & $40(66.67 \%)$ \\
Exophthalmos (proptosis) & $16(26.67 \%)$ \\
Lid retraction & $13(21.67 \%)$ \\
Conjunctival injection & $11(18.33 \%)$ \\
Exaggerated deep-tendon reflexes & $36(60 \%)$ \\
Wide pulse pressure & $32(53.33 \%)$ \\
Hypertension & $12(20 \%)$ \\
Antithyroid antibodies & \\
TRAb-positive patients $n(\%)$ level of antibodies against TSH & $57(95 \%)$ \\
receptor more than $1.1 \mathrm{U} / \mathrm{L}$ & $42(70 \%)$ \\
AntiTPO-positive patients $n(\%)$ level of antibodies against TPO & $14(23.33 \%)$ \\
$\quad$ more than 12 U/L & \\
$\quad$ montiTg-positive patients $n(\%)$ level of antibodies against Tg & \\
\hline
\end{tabular}

as thyroid-related peptide [7]. Once this complex is formed, the $\mathrm{T}$ cell requires an additional stimulus to proliferate and secrete cytokines [8]. Thyroid cells express MHC molecules in autoimmune thyroid diseases and may express co-stimulatory molecules, aiding in intrathyroidal $\mathrm{T}$ cell activation. On the other hand, modifying the $\mathrm{B}$ cell repertoire is an effective treatment option for example in Graves orbitopathy, indicating that B cells may play role in GD development [9, 10].

Magnesium (Mg) is a very important electrolyte for cell homeostasis [11]. Mg acts as a cofactor of many enzymes and is involved in a variety of biological functions, including structural and regulatory intracellular balance. $\mathrm{Mg}$ deficiency is connected with the development of various autoimmune diseases including GD. This electrolyte stabilises mitochondrial linkage and regulates oxidative and ATP synthesis processes [12]. Hypomagnesaemia may deregulate lymphocyte electrolyte balance [13]. It also plays an additional role in modulating the immune response. Some works have implicated free $\mathrm{Mg}$ in T-cell activation [14]. Mg is an essential cofactor for polyphosphate compounds, the phosphoryl transfer of ATP-dependent enzymes, and the stability of membrane phospholipids [15-18]. Free $\mathrm{Mg}$ can act as a second messenger in rapid intracellular signalling and leads to lymphocyte activation [19-22].

Methimazole (MMI) has long been used to treat hyperthyroidism caused by GD. The typical MMI dose is $0.2-$ $0.5 \mathrm{mg} / \mathrm{kg}$ per day, with a range from 0.1 to $1.0 \mathrm{mg} / \mathrm{kg}$ per day [23]. Although it lowers the levels of thyroid autoantibodies, sometimes leading to long-term remission [24-27], there is still little known about its influence on human cellmediated immune response. The impact of MMI treatment on lymphocyte activation and $\mathrm{Mg}$ concentration has not been investigated in adolescents with GD.

The aim of this research was to describe the frequencies of activated $\mathrm{T}$ lymphocytes, including $\mathrm{T}$ CD4+ and
Table 2 Hormone levels in study and control group

\begin{tabular}{|c|c|c|c|c|}
\hline & & $\begin{array}{l}\text { Study group before } \\
\text { the treatment }\end{array}$ & $\begin{array}{l}\text { Study group after } \\
\text { achieving euthyreosis }\end{array}$ & Control group \\
\hline \multirow[t]{3}{*}{ TSH [mU/1] } & Mean $\pm \mathrm{SD}$ & $0.01 \pm 0.01$ & $0.09 \pm 0.25$ & $2.71 \pm 0.91$ \\
\hline & Median & 0.005 & 0.01 & 2.78 \\
\hline & (Min-max) & $(0.001-0.094)$ & $(0.002-1.33)$ & $(0.92-3.98)$ \\
\hline \multirow[t]{3}{*}{ FT3 [pmol/1] } & Mean \pm SD & $11.92 \pm 3.79$ & $5.85 \pm 1.24$ & $4.97 \pm 0.74$ \\
\hline & Median & 12.34 & 5.85 & 4.88 \\
\hline & (Min-max) & $(6.23-35.79)$ & $(3.78-7.66)$ & $(3.6-6.4)$ \\
\hline \multirow[t]{3}{*}{ FT4 [pmol/1] } & Mean \pm SD & $35.61 \pm 14.19$ & $17.03 \pm 2.59$ & $17.27 \pm 1.99$ \\
\hline & Median & 31.78 & 16.54 & 17.03 \\
\hline & $(\operatorname{Min}-\max )$ & $(18.36-87.22)$ & $(12.23-22.39)$ & (14-21.47) \\
\hline
\end{tabular}


Table 3 Frequencies of activated lymphocytes in study and control group

\begin{tabular}{|c|c|c|c|c|}
\hline & & $\begin{array}{l}\text { Study group before } \\
\text { the treatment }\end{array}$ & $\begin{array}{l}\text { Study group after } \\
\text { achieving euthyreosis }\end{array}$ & Control group \\
\hline \multirow[t]{3}{*}{$\mathrm{CD} 3+\mathrm{CD} 25+[\%]$} & Mean \pm SD & $11.05 \pm 3.58$ & $9.72 \pm 3.29$ & $8.91 \pm 3.13$ \\
\hline & Median & 11.86 & 9.79 & 9.14 \\
\hline & (Min-max) & $(2.31-32.59)$ & $(2.34-13.73)$ & $(2.12-11.21)$ \\
\hline \multirow[t]{3}{*}{$\mathrm{CD} 19+\mathrm{CD} 25+[\%]$} & Mean \pm SD & $5.62 \pm 4.91$ & $3.35 \pm 2.24$ & $3.17 \pm 1.97$ \\
\hline & Median & 5.94 & 3.85 & 3.58 \\
\hline & $(\operatorname{Min}-\max )$ & $(2.23-14.59)$ & $(1.78-6.26)$ & $(1.16-5.14)$ \\
\hline \multirow[t]{3}{*}{$\mathrm{CD} 4+\mathrm{CD} 25+[\%]$} & Mean \pm SD & $10.12 \pm 14.19$ & $7.53 \pm 5.59$ & $7.02 \pm 4.58$ \\
\hline & Median & 10.08 & 7.44 & 6.93 \\
\hline & $(\operatorname{Min}-\max )$ & $(1.36-32.22)$ & $(2.23-18.39)$ & $(1.05-11.47)$ \\
\hline \multirow[t]{3}{*}{$\mathrm{CD} 8+\mathrm{CD} 25+[\%]$} & Mean \pm SD & $4.21 \pm 4.01$ & $2.15 \pm 2.25$ & $1.17 \pm 1.19$ \\
\hline & Median & 4.13 & 2.12 & 1.08 \\
\hline & (Min-max) & $(0.32-14.15)$ & $(0.12-5.43)$ & $(0.11-3.76)$ \\
\hline \multirow[t]{3}{*}{$\mathrm{CD} 3+\mathrm{CD} 69+[\%]$} & Mean \pm SD & $4.92 \pm 5.79$ & $2.25 \pm 2.24$ & $2.07 \pm 1.74$ \\
\hline & Median & 5.02 & 2.31 & 1.96 \\
\hline & (Min-max) & $(0.61-13.86)$ & $(0.19-5.63)$ & $(0.18-3.02)$ \\
\hline \multirow[t]{3}{*}{$\mathrm{CD} 19+\mathrm{CD} 69+[\%]$} & Mean \pm SD & $4.61 \pm 4.76$ & $2.93 \pm 2.36$ & $2.57 \pm 1.99$ \\
\hline & Median & 4.58 & 3.04 & 2.73 \\
\hline & (Min-max) & $(0.95-13.52)$ & $(0.43-5.03)$ & $(0.27-4.00)$ \\
\hline \multirow[t]{3}{*}{$\mathrm{CD} 4+\mathrm{CD} 69+[\%]$} & Mean \pm SD & $2.75 \pm 3.90$ & $1.15 \pm 1.27$ & $0.91 \pm 1.02$ \\
\hline & Median & 2.13 & 1.08 & 1.01 \\
\hline & (Min-max) & $(0.23-7.11)$ & $(0.08-2.41)$ & $(0.09-1.49)$ \\
\hline \multirow[t]{3}{*}{$\mathrm{CD} 8+\mathrm{CD} 69+[\%]$} & Mean \pm SD & $2.84 \pm 3.68$ & $1.25 \pm 1.85$ & $1.07 \pm 0.93$ \\
\hline & Median & 2.76 & 1.17 & 0.92 \\
\hline & (Min-max) & $(0.34-6.56)$ & $(0.09-2.91)$ & $(0.08-1.52)$ \\
\hline
\end{tabular}

T CD8+, and B lymphocytes in adolescents with hyperthyroidism due to GD and to assess changes in the amount of these cell subsets during MMI treatment. Relations between activated lymphocytes, plasma $\mathrm{Mg}$ concentration, and selected clinical parameters were also assessed.

\section{Material and Methods}

Patients and Controls

Study group comprised of 60 previously untreated adolescent patients with hyperthyroidism due to GD (mean
Fig. 1 Percentages of $\mathrm{CD} 3+\mathrm{CD} 25+$ cells in the study group before the treatment and after achieving euthyreosis, and in the control group

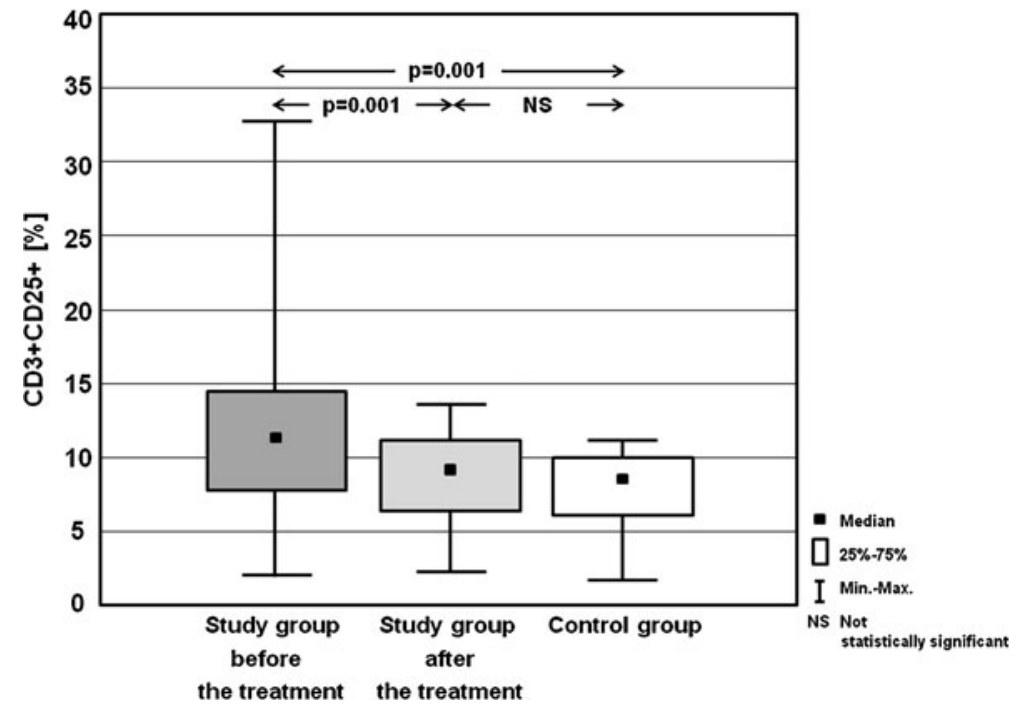


Fig. 2 Percentages of CD19+CD25+ cells in the study group before the treatment and after achieving euthyreosis, and in the control group

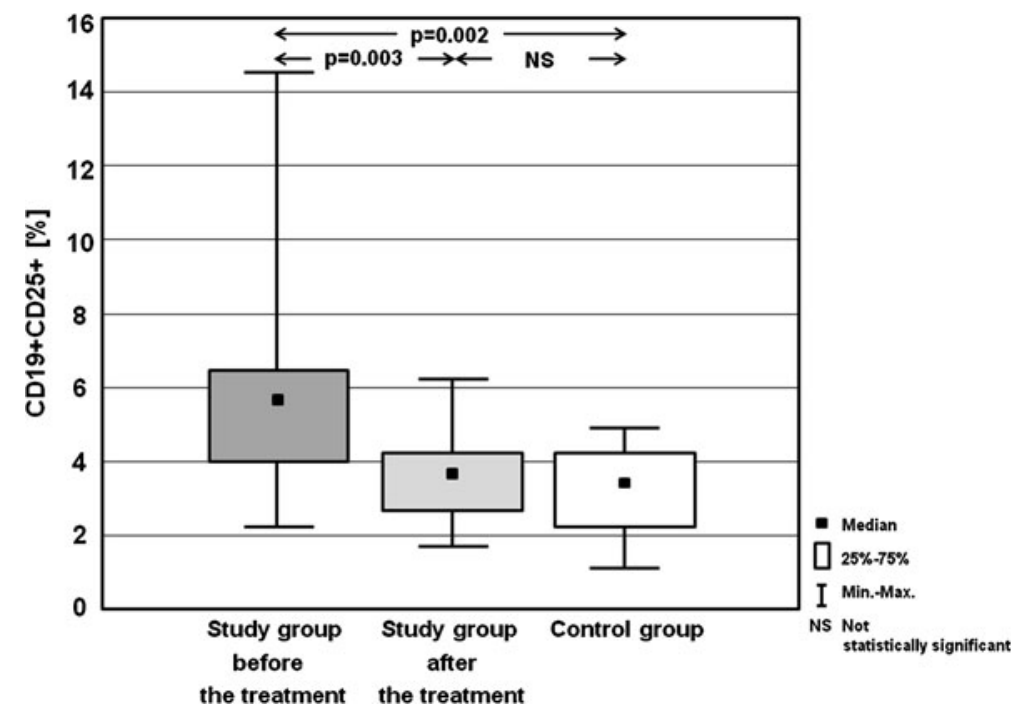

age, $14.07 \pm 1.94$; median, 14 ; min-max, $11-17.4$ years; 48 females, 12 males), hospitalised in the Department of Paediatrics, Division of Paediatric Endocrinology and Diabetology, Medical University of Lublin, Poland. Twenty healthy donors (mean age, $14.47 \pm 2.21$; median, 14.65; min-max, 11-17.5 years; 15 females, five males) served as a control group. The patients were diagnosed on the basis of clinical examination as well as morphological and immunological criteria. In the group of examined children, each presented a wide variety of clinical manifestations of hyperthyroidism at the time of diagnosis. Before antithyroid treatment initiation, blood samples from every child were collected and lymphocyte subsets, plasma $\mathrm{Mg}$ concentration, thyroidstimulating hormone (TSH), free thyroxine (FT4) and free triiodothyronine (FT3) hormone levels were measured.
The patients were treated with MMI at initial doses of $0.51 \pm 0.05 \mathrm{mg} / \mathrm{kg}$ body weight/day during approximately 4 6 weeks, and after that time, when in euthyroidism, blood samples were collected again to assess lymphocyte subsets, $\mathrm{Mg}$ concentration and hormone levels. Later the patients received maintenance doses of approximately $0.1-0.2 \mathrm{mg} / \mathrm{kg}$ body weight/day MMI in combination with a low dose of Lthyroxin. Median time of patients' observation amounted to 36 months.

None of the patients and controls had signs of infection at the time of investigation and for a month before sampling, none had been taking drugs of known influence on the immune system. None of the patients or healthy donors had undergone blood transfusion. Persons with a history of allergic diseases were excluded from the study. The research protocol was approved by the Ethics Committee of the Medical
Fig. 3 Percentages of $\mathrm{CD} 4+\mathrm{CD} 25+$ cells in the study group before the treatment and after achieving euthyreosis, and in the control group

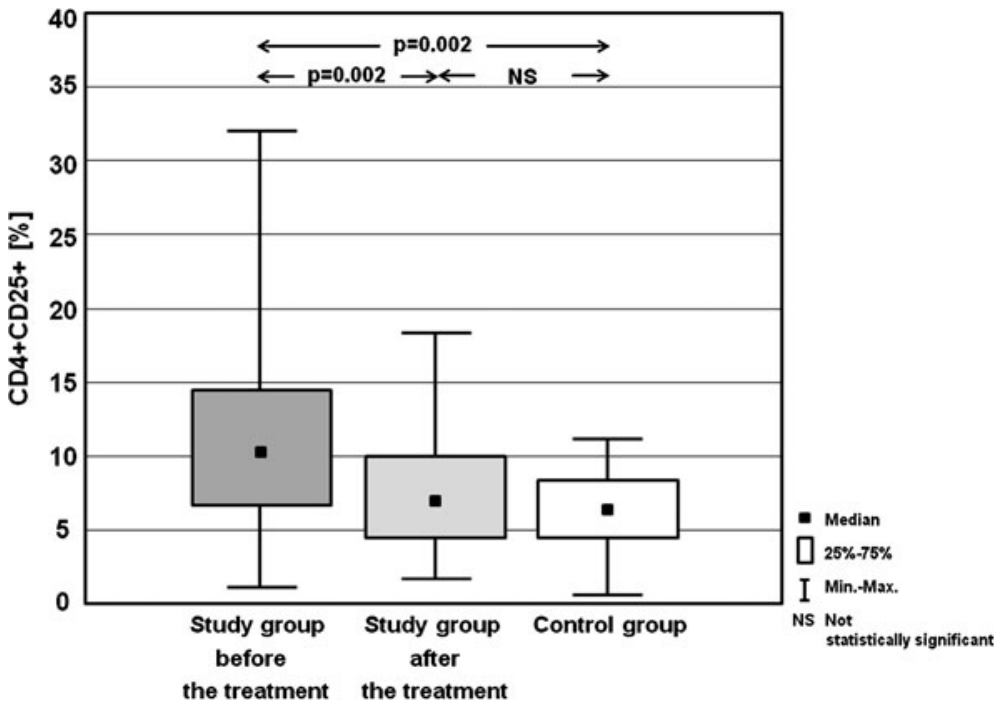


Fig. 4 Percentages of CD8+CD25+ cells in the study group before the treatment and after achieving euthyreosis, and in the control group

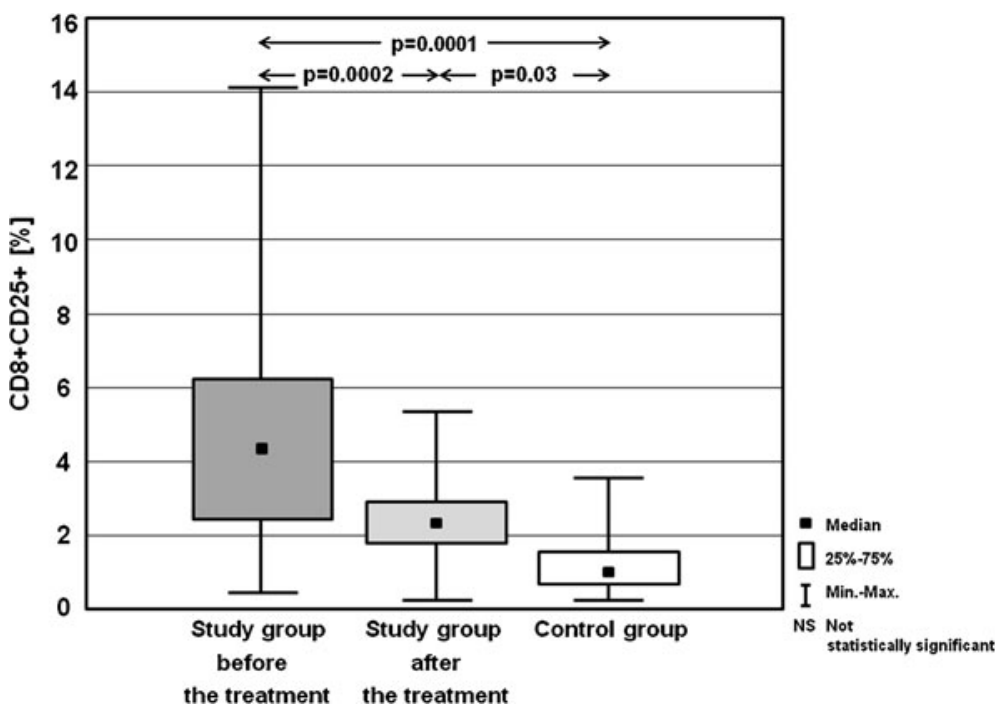

University of Lublin and all patients gave written informed consent.

Assessment of Plasma Mg Concentration, Thyroid-Stimulating hormone, Free Thyroxine, Free Triiodothyronine, TSH Receptor Antibodies, Thyroid Peroxidise Antibodies and Thyroglobulin Antibodies Levels

Using microparticle enzyme immunoassay (Abbott Kit), FT4 and FT3 hormones were assayed. The levels of TSH receptor antibodies (TRAb) were measured by radioimmunoassay (TRAK assay, BRAHMS Diagnostica GmbH, Berlin, Germany). Thyroid peroxidase (TPO) and thyroglobulin (Tg) antibodies were assayed by luminescence immunoassay (Lumitest, BRAHMS Diagnostica $\mathrm{GmbH}$ ). The plasma $\mathrm{Mg}$ concentrations were determined by spectrophotometric methods. The following reference intervals were determined: TSH 0.27-4.2 mU/1, FT4 1.06-1.8 ng/dl, FT3 $2.28-5 \mathrm{pg} / \mathrm{ml}$ and $\mathrm{Mg} 1.9-2.5 \mathrm{mg} / \mathrm{dl}$. Levels of antibodies against TSH receptor less than $1.1 \mathrm{U} / 1, \mathrm{Tg}$ antibodies less than $35 \mathrm{U} / 1$ and TPO antibodies less than $12 \mathrm{U} / 1$ were considered normal.

Isolation of Peripheral Blood Cells and the Detection of Activated T and B Lymphocytes

Venous blood samples were collected from the study patients and controls by venipuncture using sterile, lithium heparintreated tubes (S-Monovette, SARSTEDT, Aktiengesellschaft \& Co., D-51588 Nubrecht, Germany).
Fig. 5 Percentages of CD3+CD69+ cells in the study group before the treatment and after achieving euthyreosis, and in the control group

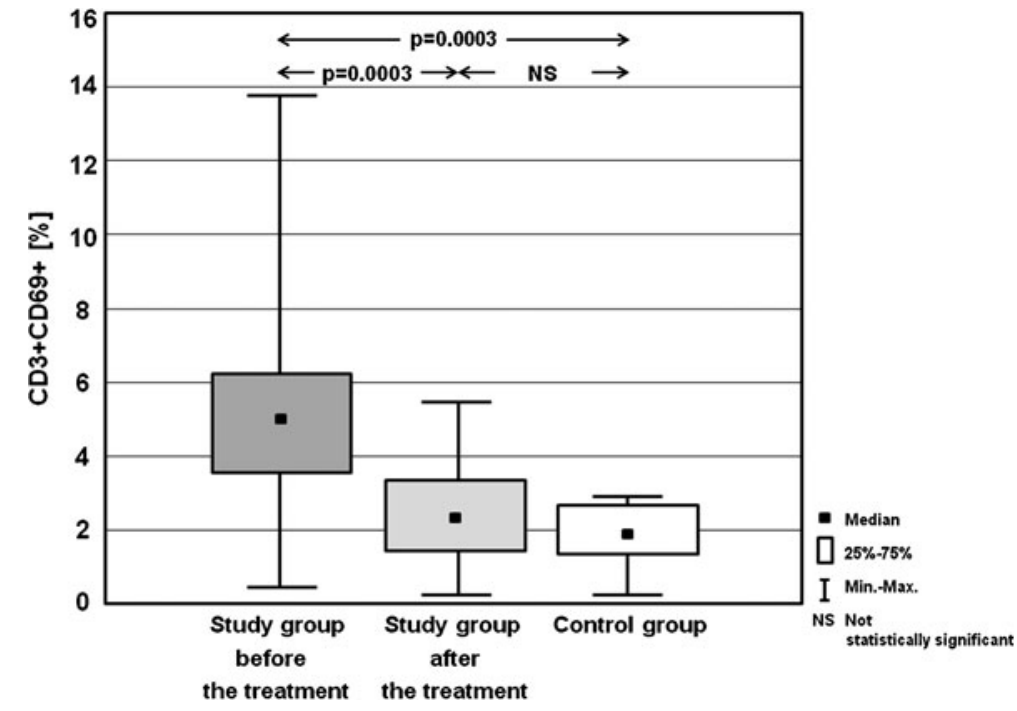


Fig. 6 Percentages of CD19+CD69+ cells in the study group before the treatment and after achieving euthyreosis, and in the control group

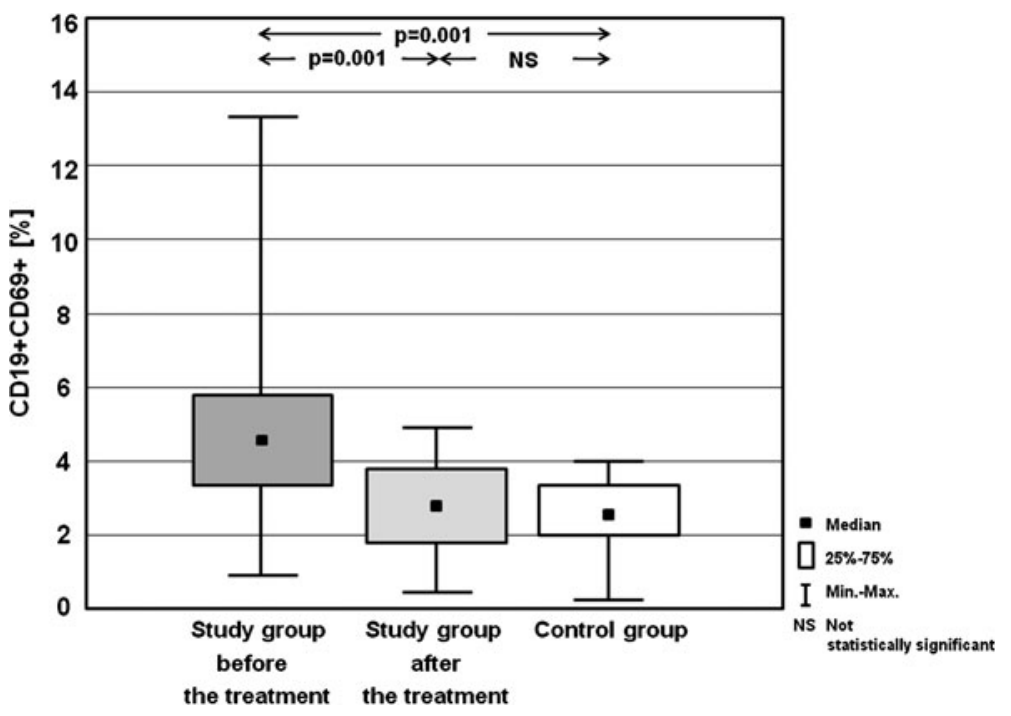

Peripheral blood mononuclear cells were aseptically separated by a standard density gradient centrifugation (Gradisol L, Aqua Medica, Poland). The percentage of cells expressing surface markers were analysed. The cells were phenotypically characterised by incubation (20 $\mathrm{min}$ in the dark at a room temperature) with combination of relevant fluorescein isothiocyanate (FITC) - phycoerythrin (PE) - and CyChrome-labelled monoclonal antibodies (mAbs). Immunofluorescence studies were performed using a combination of the following mAbs: CD3 PE, CD19 PE, CD3 FITC/CD19 PE, CD4 PE, CD8 PE, CD8 FITC/CD4 PE, CD25 CyChrome and CD69 CyChrome, purchased from BD Biosciences (USA). Three-colour immunofluorescence analyses were performed using a FACS Calibur flow cytometer (Becton Dickinson) equipped with $488 \mathrm{~nm}$ argon laser. A minimum of 10,000 events was acquired and analysed using CellQuest Software. The results were presented as percentage of CD45+ cells stained with antibody. The percentage of positive cells was calculated by comparing with the control. Background fluorescence was determined using isotype-matched directly conjugated mouse anti IgG1/IgG2 $\alpha$ monoclonal antibodies. The samples were gated on forward scatter vs. side scatter to exclude debris and cell aggregates.

\section{Statistical Analysis}

Statistical analysis of the results was conducted using Statistica 9.0. Deviation from normality was evaluated by Kolmogorov-Smirnov test. Data were expressed as the mean
Fig. 7 Percentages of CD4+CD69+ cells in the study group before the treatment and after achieving euthyreosis, and in the control group

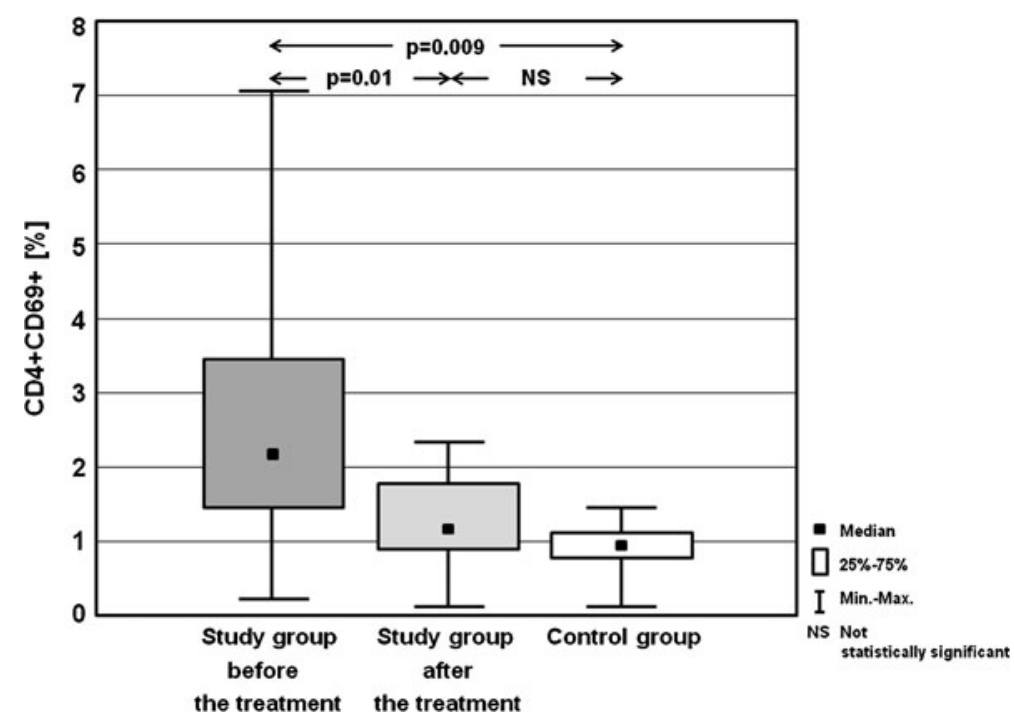


Fig. 8 Percentages of CD8+CD69+ cells in the study group before the treatment and after achieving euthyreosis, and in the control group

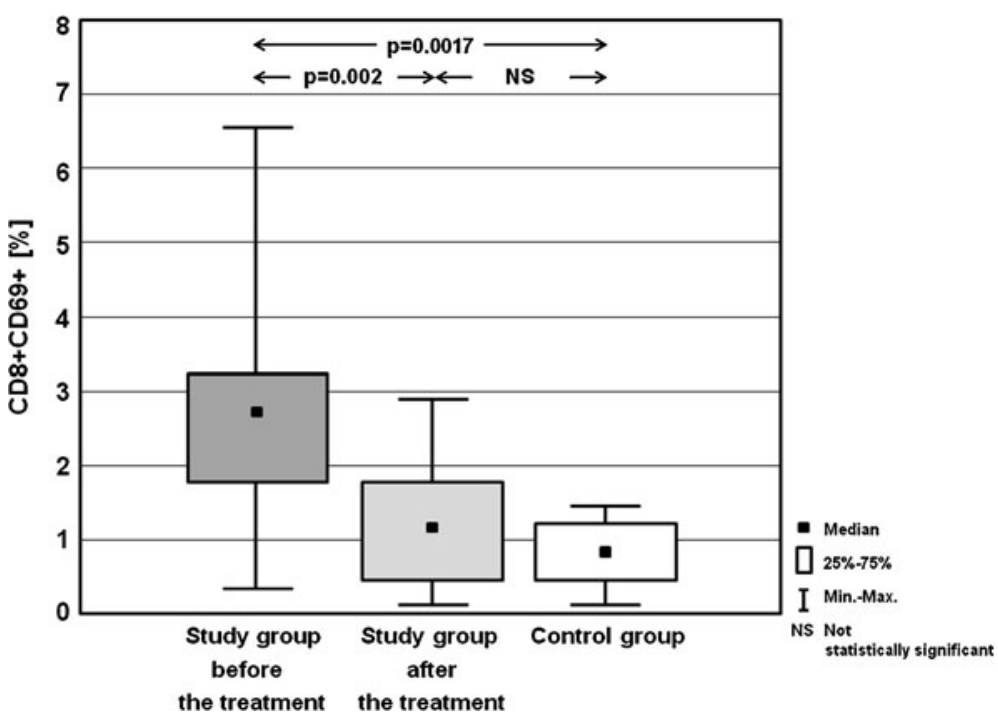

value $\pm \mathrm{SD}$, median, minimum and maximum. Differences between groups were assessed using the Mann-Whitney $U$ test. Pearson or Spearman correlation analyses were used to analyse the correlation. A value $p$ less than 0.05 was considered statistically significant.

\section{Results}

Patient Characteristics. Differences in Basic Tested Parameters Between Study and Control Group

Patient baseline characteristics are demonstrated in Table 1. Table 2 presents differences in basic tested parameters between study and control group.
Serum levels of TSH, FT3 and FT4 before the treatment were statistically significantly different from those observed in the control group $(p<0.00001, p<0.00001$ and $p<0.00001$, respectively). We also found relevant differences between TSH, FT3 and FT4 levels in adolescents with GD after receiving euthyreosis, and in healthy individuals $(p<0.00001$, $p=0.001$ and $p=0.012$, respectively). Comparison between patients before the treatment and in euthyreosis revealed significant differences in serum TSH, FT3 and FT4 levels ( $p=0.007, p<0.00001$ and $p=0.001$, respectively).

\section{Activated T and B Cells}

Table 3 presents the frequencies of activated $\mathrm{T}$ lymphocytes (CD3+CD25+, CD3+CD69+), T helper cells (CD4+CD25+,
Fig. 9 Plasma Mg concentration in the study group before the treatment and after achieving euthyreosis, and in the control group

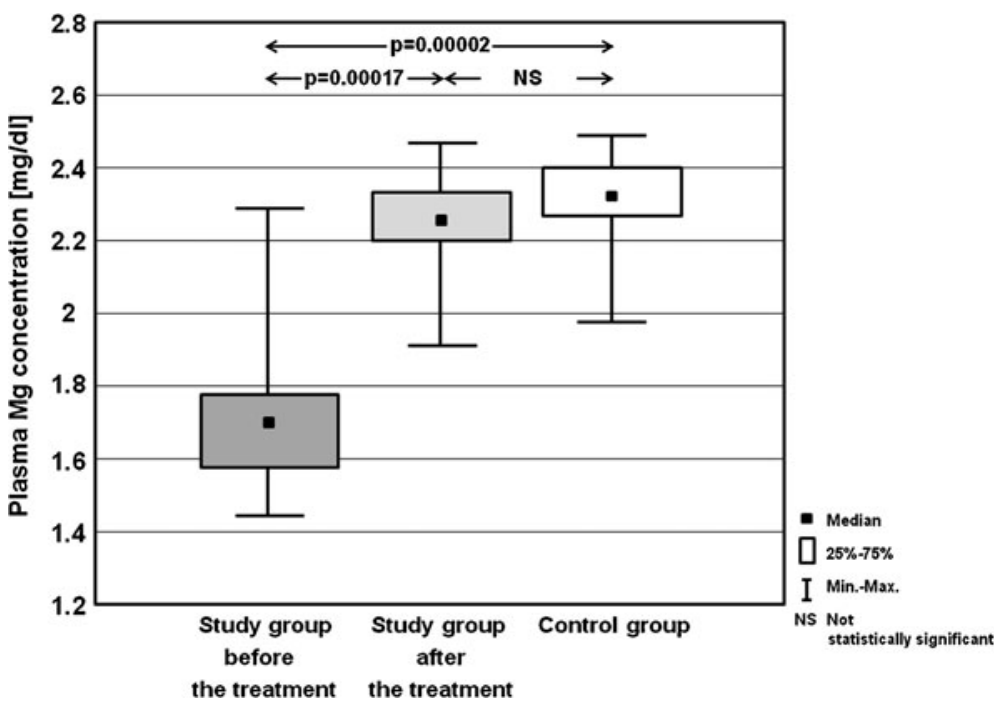


Fig. 10 A negative correlation between the percentages of $\mathrm{CD} 3+\mathrm{CD} 25+$ cells and plasma $\mathrm{Mg}$ concentration before the treatment in the study group $(r=-0.645, p<0.00001)$

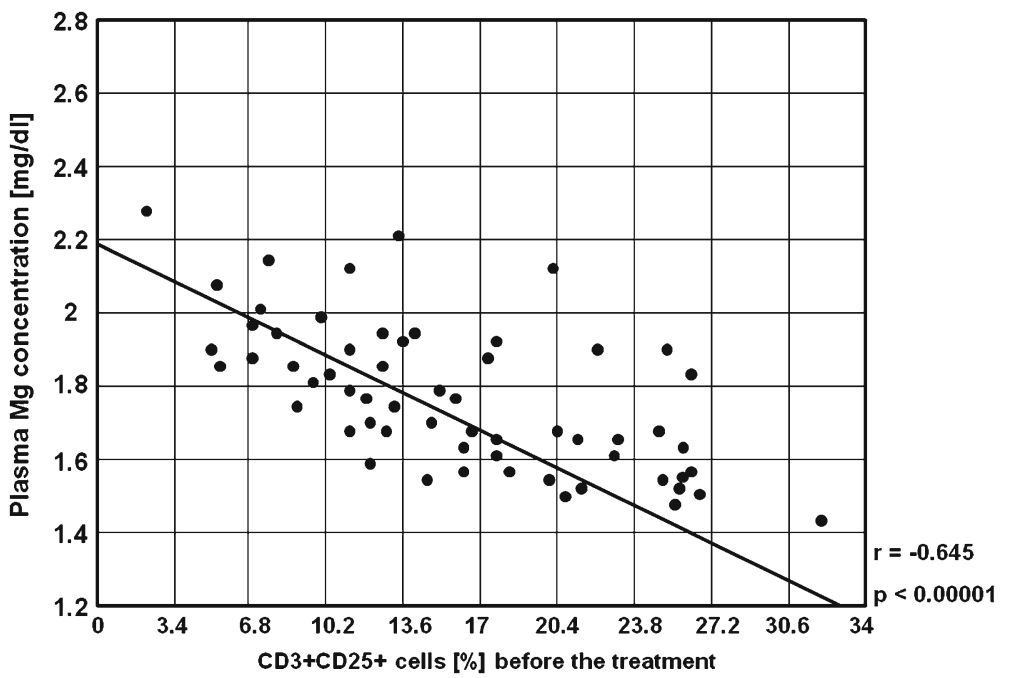

CD4+CD69+), T cytotoxic cells $(\mathrm{CD} 8+\mathrm{CD} 25+, \mathrm{CD} 8+$ CD69+) and B cells (CD19+CD25+, CD19+CD69+). Statistically significant differences in the percentages of the analysed cells between study group before the treatment, and in MMI-induced euthyreosis, and control group are presented on the Figs. 1, 2, 3, 4, 5, 6, 7 and 8.

\section{Plasma Mg Concentration in Control and Study Groups}

Statistically significantly lower plasma $\mathrm{Mg}$ concentration was noted in adolescents with GD (mean, $1.72 \pm 0.13 \mathrm{mg} / \mathrm{dl}$; median, $1.73 \mathrm{mg} / \mathrm{dl}$; min, $1.43 \mathrm{mg} / \mathrm{dl}$; max, $2.29 \mathrm{mg} / \mathrm{dl}$ ) than in control subjects (mean, $2.36 \pm 0.19 \mathrm{mg} / \mathrm{dl}$; median, $2.32 \mathrm{mg} / \mathrm{dl}$; $\min , 1.98 \mathrm{mg} / \mathrm{dl} ; \max , 2.49 \mathrm{mg} / \mathrm{dl} ; p=0.00002)$ and study group after achieving euthyreosis (mean, 2.28 $0.21 \mathrm{mg} / \mathrm{dl}$; median, $2.26 \mathrm{mg} / \mathrm{dl}$; $\mathrm{min}, 1.91 \mathrm{mg} / \mathrm{dl}$; $\max , 2.43 \mathrm{mg} / \mathrm{dl} ; p=0.00017)$. No difference in $\mathrm{Mg}$ level was observed between children in euthyreosis and control group ( $p=0.1$ ). Figure 9 presents $\mathrm{Mg}$ plasma levels in the analysed groups.

Relations Between Mg Plasma Concentration and the Frequencies of Peripheral Activated T and B Cells in Hyperthyroid Adolescents

Statistically significant negative correlations between the percentages of activated $\mathrm{T}$ CD3+, $\mathrm{T}$ CD4+, T CD8+ and $\mathrm{B}$ CD19+ lymphocytes, and plasma Mg concentration before the treatment were found (Figs. 10, 11, 12, 13, 14, $15,16,17$ and 18). In the study group in MMI-induced euthyreosis, and in the control group no significant correlations were found.
Fig. 11 A negative correlation between the percentages of CD19+CD25+ cells and plasma $\mathrm{Mg}$ concentration before the treatment in the study group $(r=-0.484, p=0.00001)$

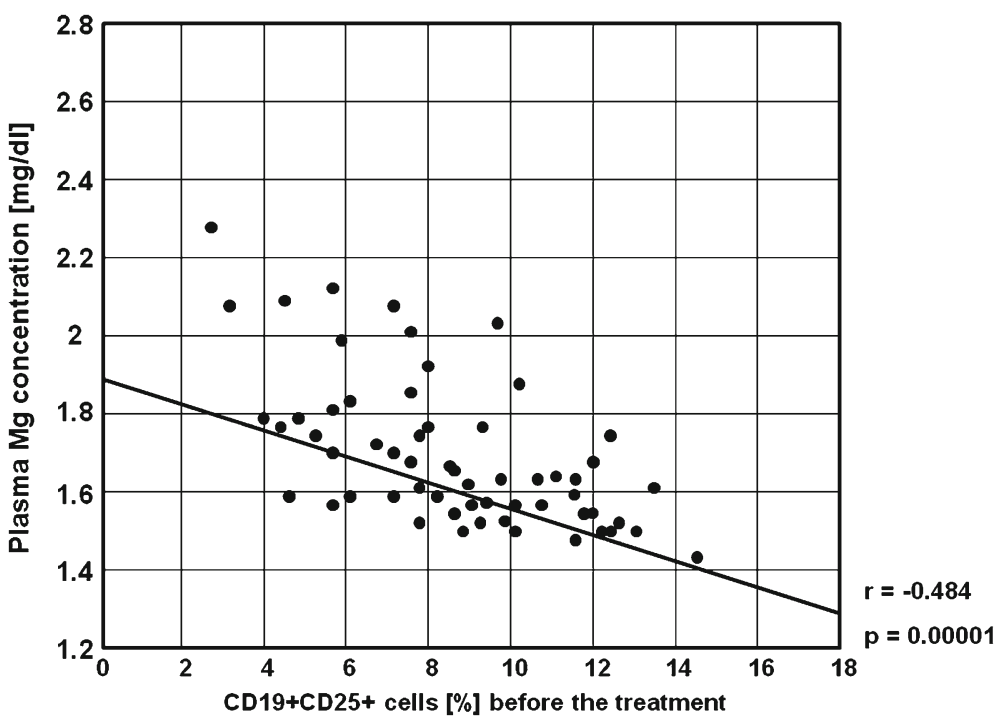


Fig. 12 A negative correlation between the percentages of $\mathrm{CD} 4+\mathrm{CD} 25+$ cells and plasma $\mathrm{Mg}$ concentration before the treatment in the study group $(r=-0.741, p<0.00001)$

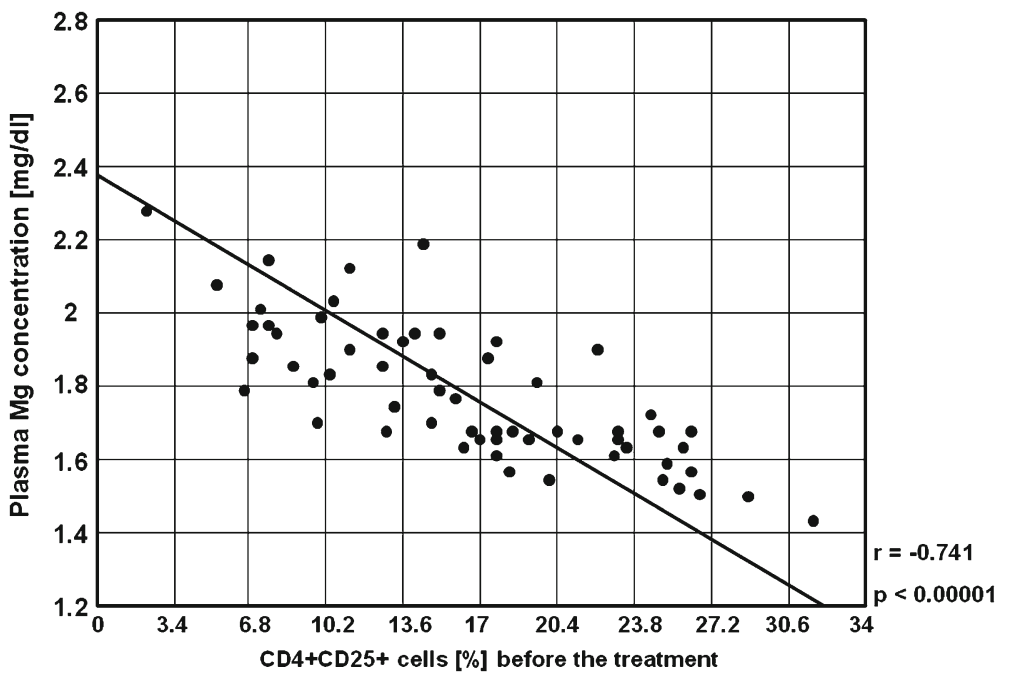

Relations Between the Frequencies of Peripheral Activated $\mathrm{T}$ and B Cells, and Selected Clinical Parameters Including Hormone Levels in Hyperthyroid Adolescents

It was found that there were strong positive correlations between serum concentration of FT3 before the treatment and the frequencies of CD19+CD25+ B lymphocytes $(r=0.793$, $p<0.00001$, Fig. 18), CD3+CD69+ T lymphocytes $(r=0.624$, $p<0.00001$, Fig. 19), CD4+CD69+ T lymphocytes $(r=0.761$, $p<0.00001$, Fig. 20) and CD8+CD69+ T lymphocytes $(r=0.499, p<0.00001$, Fig. 21).

Positive, although less prominent, correlations between the serum concentration of FT4 and the percentages of CD3+CD25+ cells, CD19+CD25+ cells, CD4+CD25+ cells, CD8+CD25+ cells, CD3+CD69+ cells and CD19+ CD69+ cells were observed $(r=0.312, p=0.003 ; r=0.281$, $p=0.01 ; r=0.279, p=0.01 ; r=0.273, p=0.01 ; r=0.276$, $p=0.02$ and $r=0.241, p=0.03$, respectively).
Frequencies of activated B CD19+CD25+ lymphocytes positively correlated with the thyroid gland volume $(r=$ $0.282, p=0.029$ ) as well as with the volume of its left lobe $(r=0.306, p=0.017)$.

The percentages of activated T CD4+CD25+, and T CD8+ CD25+ cells before the treatment negatively correlated with the elapsed time from achieving euthyreosis to the relapse of hyperthyroidism $(r=-0.269, p=0.03$, and $r=-0.291, p=0.02$, respectively). The lower values of activated T cells were noted before the treatment, the longer GD remission was observed.

Relations Between Plasma Mg Concentration and Selected Clinical Parameters, Including Hormone Levels in Hyperthyroid Adolescents

Plasma Mg concentration before the treatment was negatively correlated with FT3 and FT4 serum levels $(r=0.301$, $p=0.01$ and $r=0.294, p=0.02$, respectively).
Fig. 13 A negative correlation between the percentages of $\mathrm{CD} 8+\mathrm{CD} 25+$ cells and plasma $\mathrm{Mg}$ concentration before the treatment in the study group $(r=-0.518, p=0.00006)$

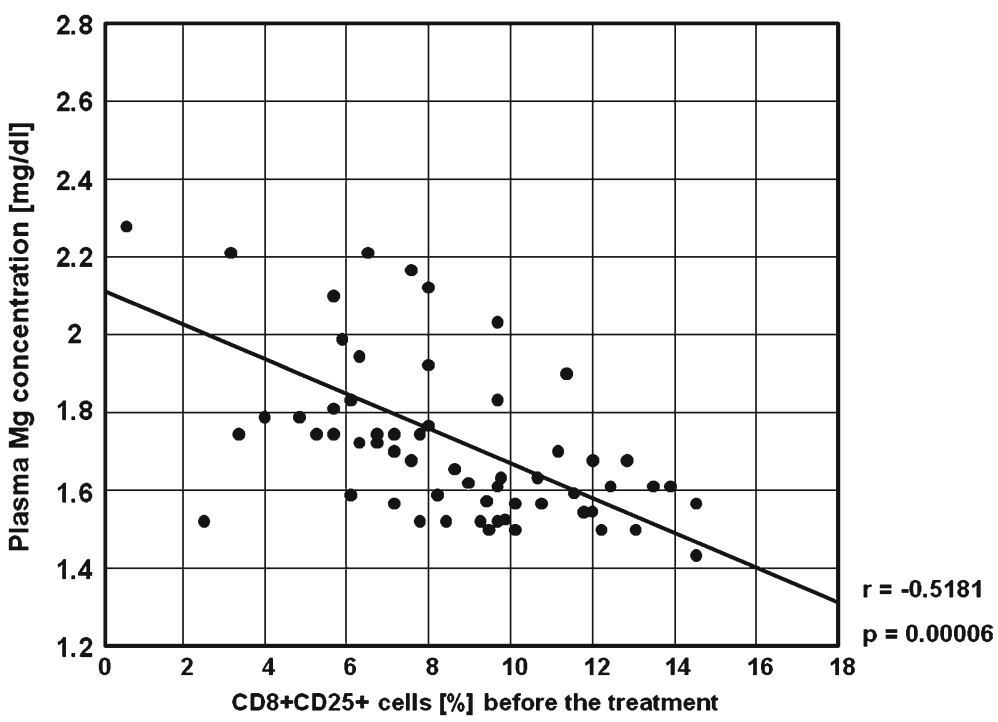


Fig. 14 A negative correlation between the percentages of CD3+CD69+ cells and plasma $\mathrm{Mg}$ concentration before the treatment in the study group $(r=-0.537, p=0.0009)$

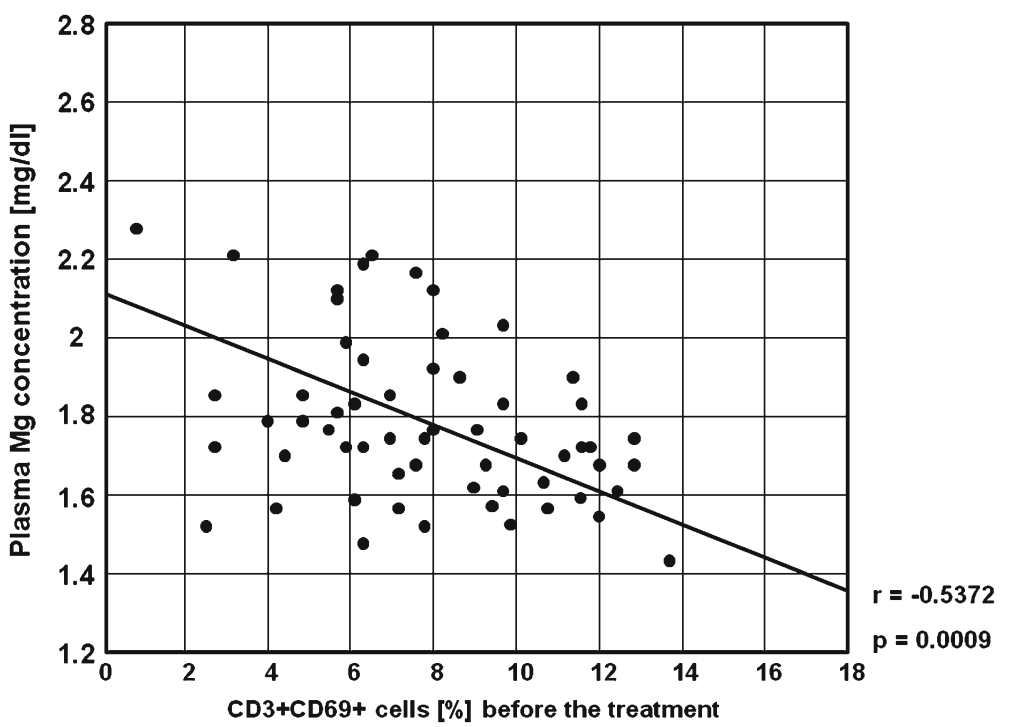

$\mathrm{Mg}$ levels before the treatment negatively correlated with the parameters describing the thyroid gland size: its total volume $(r=-0.313, p=0.015$, ), left lobe volume $(r=-0.326$, $p=0.011)$ as well as right lobe volume $(r=-0.262$, $p=0.043$ ). There was also a positive correlation between $\mathrm{Mg}$ plasma concentration before the treatment, and elapsed time from achieving euthyreosis to the relapse of hyperthyroidism $(r=0.361, p=0.03)$. Long remission was connected with higher $\mathrm{Mg}$ levels.

\section{Discussion}

Mg participates in a variety of metabolic functions [28-32]. The influence of thyroid hormones on $\mathrm{Mg}$ homeostasis is well known [33, 34], but not enough attention is paid to $\mathrm{Mg}$ impact on lymphocyte activation in hyperthyroidism. Various, often conflicting results have been reported about the plasma $\mathrm{Mg}$ concentration in hyperthyroidism. Some investigators found that plasma $\mathrm{Mg}$ was unchanged in hyperthyroidism, but others found it to be reduced [35]. In our study statistically significantly lower plasma $\mathrm{Mg}$ concentration was noted in adolescents with GD than in control subjects and in the study group after achieving euthyreosis. No difference in $\mathrm{Mg}$ level was observed between children in euthyreosis and control group. Plasma Mg concentration before the treatment was negatively correlated with FT3 and FT4 serum levels. Clinical relevance of $\mathrm{Mg}$ deficiency in hyperthyroidism is not yet known. Our study indicated that there are statistically significant negative correlations between the percentages of activated T CD3+, T CD4+, T CD8+ and B CD19+ lymphocytes, and plasma $\mathrm{Mg}$ concentration before the treatment. In the study group in MMI-induced euthyreosis and in the control group no significant correlations were found. Moreover,
Fig. 15 A negative correlation between the percentages of CD19+CD69+ cells and plasma $\mathrm{Mg}$ concentration before the treatment in the study group $(r=-0.335, p=0.0021)$

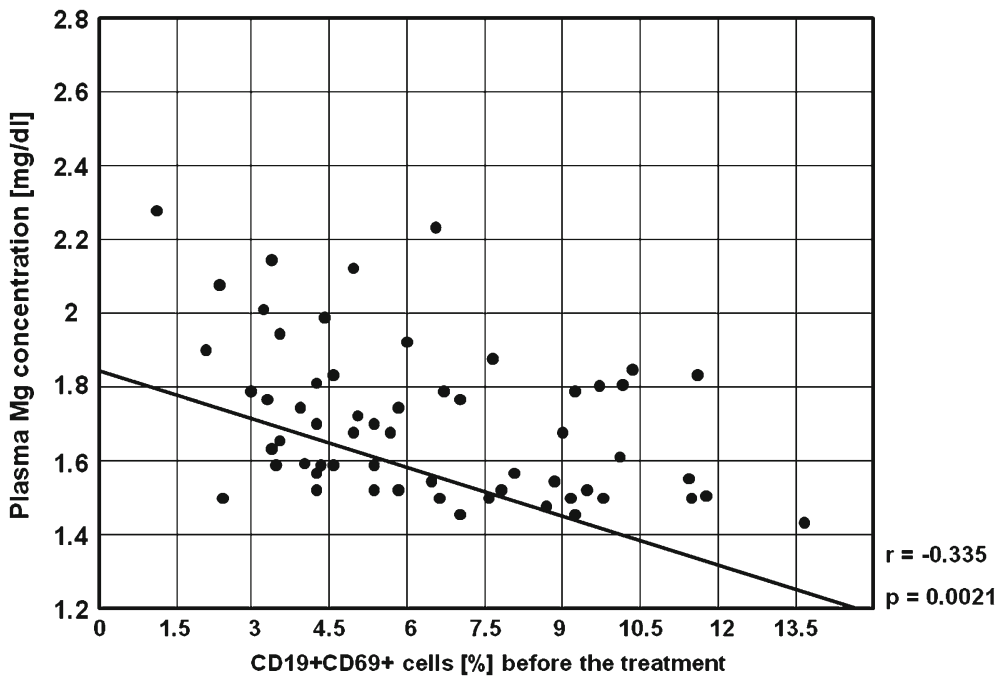


Fig. 16 A negative correlation between the percentages of CD4+CD69+ cells and plasma $\mathrm{Mg}$ concentration before the treatment in the study group ( $r=-0.453, p=0.0006$ )

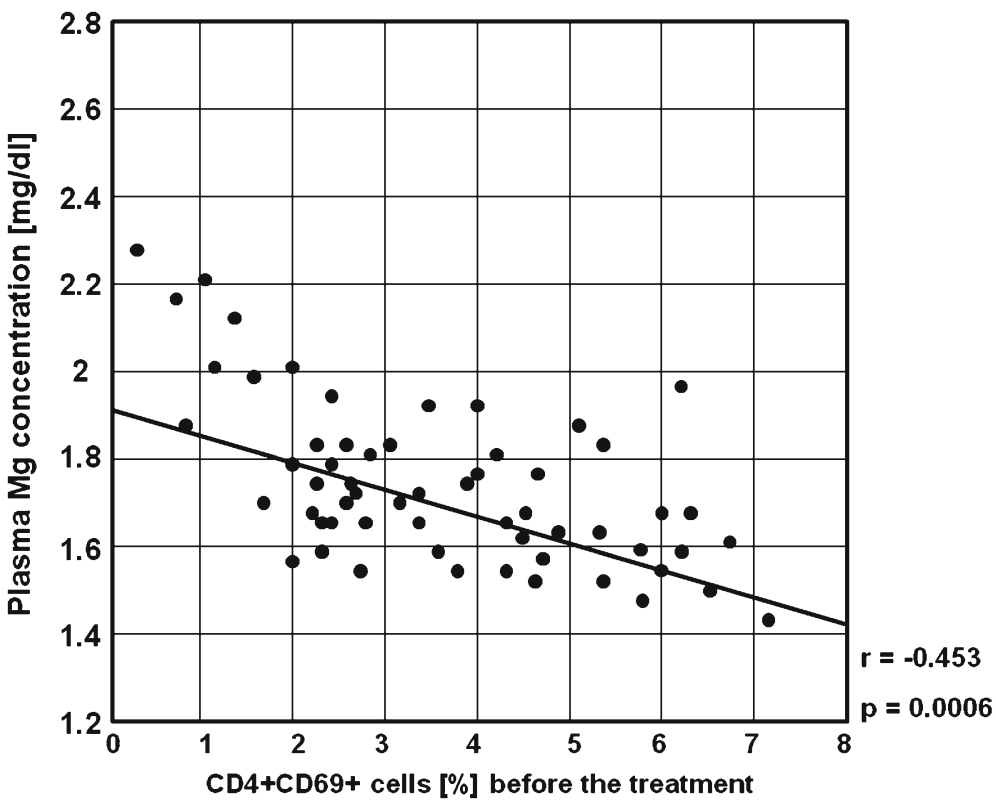

$\mathrm{Mg}$ levels before the treatment negatively correlated also with the parameters describing the thyroid gland volume. Long remission was connected with higher $\mathrm{Mg}$ levels at the time of GD diagnosis.

The activation of lymphocytes contributes to the inflammatory processes of autoimmune diseases [36-38]. We noticed higher frequencies of activated $\mathrm{T}$ lymphocytes $(\mathrm{CD} 3+\mathrm{CD} 25+, \mathrm{CD} 3+\mathrm{CD} 69+)$, $\mathrm{T}$ helper cells (CD4+CD25+, CD4+CD69+), T cytotoxic cells (CD8+ CD25+, CD $8+\mathrm{CD} 69+)$ and $\mathrm{B}$ cells $(\mathrm{CD} 19+\mathrm{CD} 25+$, $\mathrm{CD} 19+\mathrm{CD} 69+)$ in adolescents with GD before the treat- ment in comparison to healthy controls, and to the tested children after the treatment with MMI. The present study demonstrates that both $\mathrm{T}$ and $\mathrm{B} \mathrm{CD} 25+$ and CD69+ cells might play an important role in the pathogenesis of GD. Associations between IL2RA (CD25) expression and various autoimmune diseases have been reported in Caucasians [39]. Alpha-subunit of the IL-2 receptor (IL-2R $\alpha$ ) encoded by the IL2RA/CD25 gene binds IL-2 that plays a pivotal role in the regulation of $\mathrm{T}$ cell function. Levels of a soluble form of IL-2R $\alpha$ $(\operatorname{sIL}-2 \mathrm{R} \alpha)$ lacking the transmembrane and cytoplasmic
Fig. 17 A negative correlation between the percentages of CD8+CD69+ cells and plasma $\mathrm{Mg}$ concentration before the treatment in the study group $(r=-0.532, p=0.00004)$

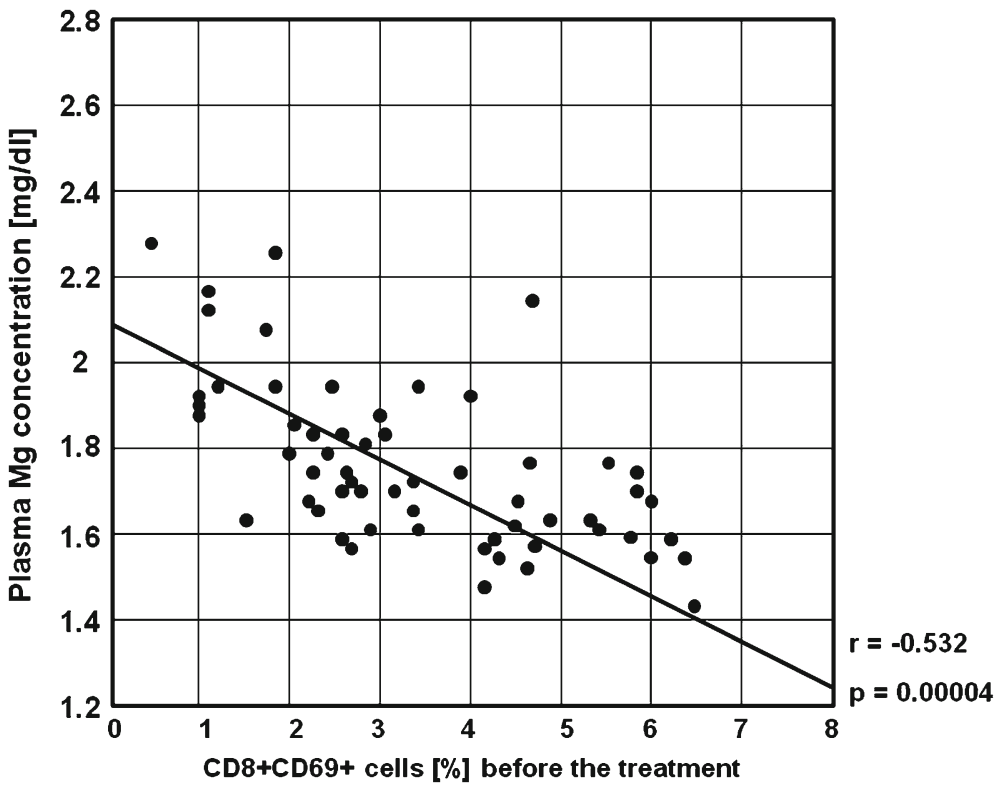


Fig. 18 A positive correlation between the percentages of CD19+CD25+ cells and serum concentration of FT3 before the treatment in the study group $(r=0.793, p<0.00001)$

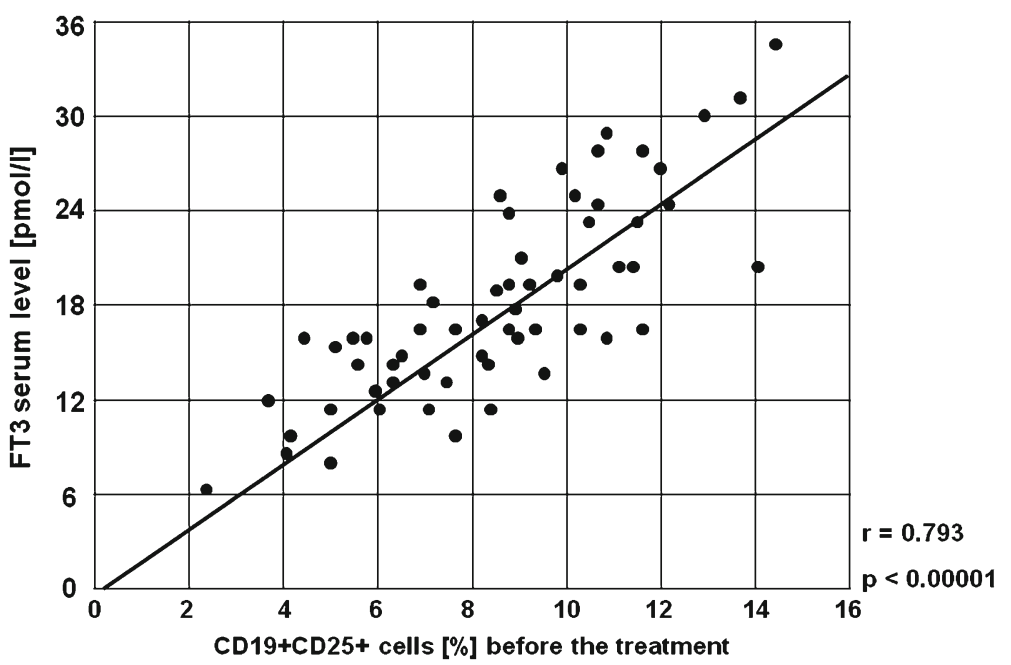

domains were shown to be increased in several autoimmune diseases including GD. Recent studies showed association between the IL2RA/CD25 gene variants and several autoimmune diseases including GD [40, 41]. However, the mechanisms by which CD25 can predispose to autoimmunity are unclear $[42,43]$. Autoimmune diseases are also connected with increased CD69 expression. The early activation antigen CD69 is a type I1 integral membrane glycoprotein included in the natural killer cell gene complex family of signal transducing receptors [44-46]. CD69 represents one of the earliest activation markers of $\mathrm{T}$ lymphocytes appearing within 1-2 $\mathrm{h}$ after stimulation [47, 48]. Consequently, CD69 expression has been used as a marker of $\mathrm{T}$ cell activation both in vivo and in vitro [49-51]. Over-expression of both CD25 and CD69 antigens in the outer membrane are observed in lymphocytes from patients with autoimmune diseases, probably as a mirror image of the immune system activation. Moreover, some of these changes are related to the disease activity [52, 53]. In the present study we found that there were strong positive correlations between serum concentration of FT3 before the treatment and the frequencies of CD19+CD25+ B lymphocytes, CD3+CD69+ T lymphocytes, CD4+CD69+ T lymphocytes and CD8+CD69+ T lymphocytes. Positive, although less prominent, correlations between the serum concentration of FT4 and the percentages of CD3+CD25+ cells, CD19+CD25+ cells, CD4+CD25+ cells, CD8+CD25+ cells, CD3+CD69+ cells and CD19+CD69+ cells were observed. Brand et al. [41] who first found association between IL2RA/CD25 and GD provided evidence for association of this locus in overall using selection of 20 tag single nucleotide polymorphisms and multilocus test for analysis. Christiakov et al. [40] found that markers rs 11594656 and rs41295061 located at the IL2RA/CD25 locus significant-
Fig. 19 A positive correlation between the percentages of CD3+CD69+ cells and serum concentration of FT3 before the treatment in the study group $(r=0.624, p<0.00001)$

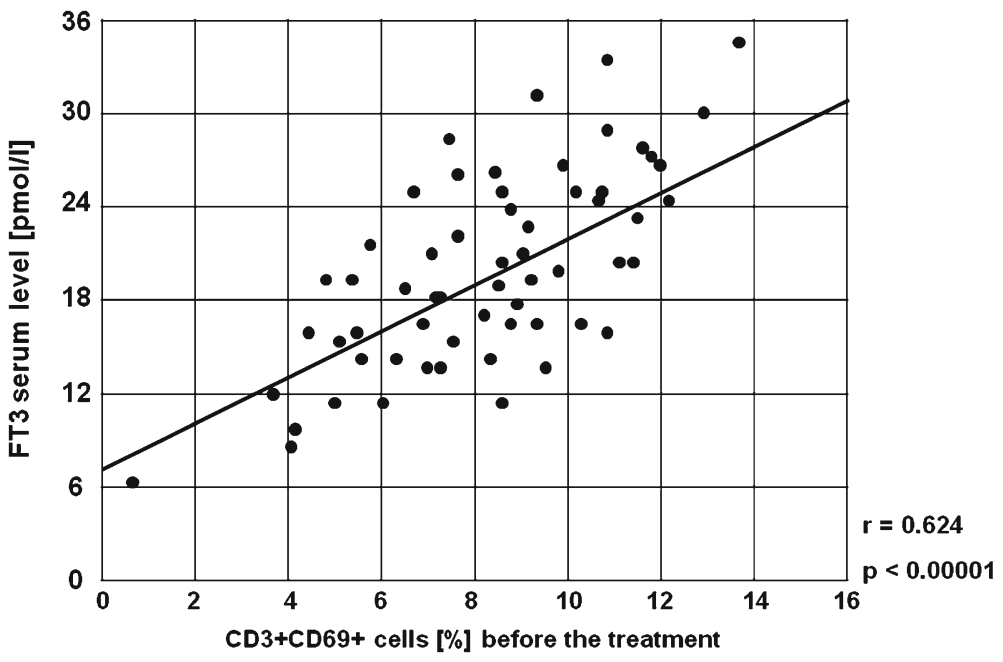


Fig. 20 A positive correlation between the percentages of CD4+CD69+ cells and serum concentration of FT3 before the treatment in the study group $(r=0.761, p<0.00001)$

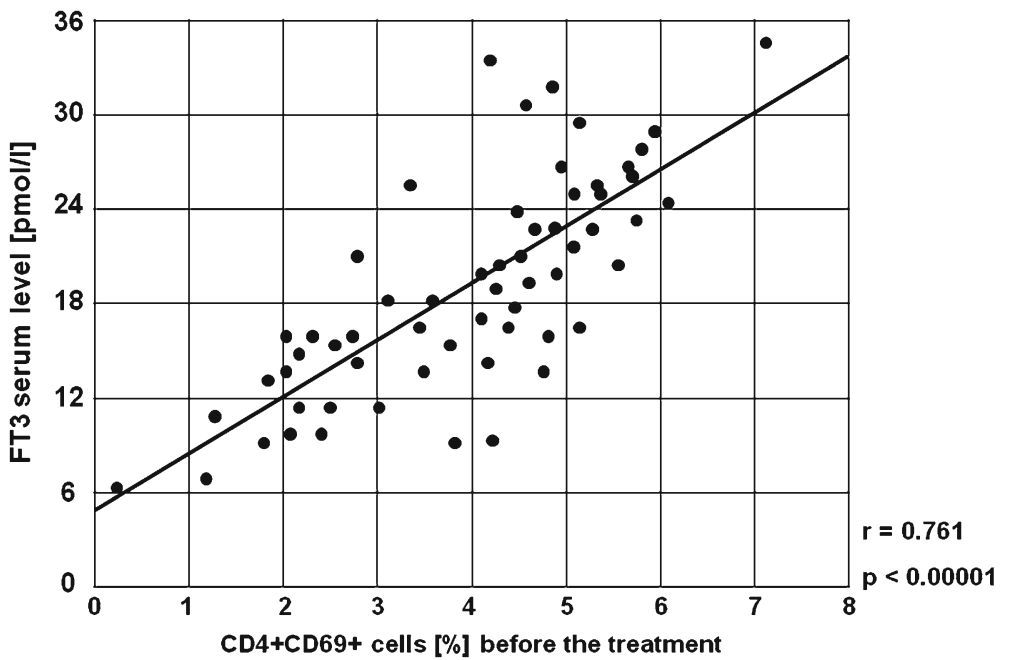

ly associated with the development of GD. Our study thereby confirms results of those authors. What is more, lymphocyte activation markers may serve as prognostic factors since the lower values of activated $\mathrm{T}$ cells were noted before the treatment, the longer GD remission was observed. We found also that frequencies of activated B CD19+CD25+ lymphocytes positively correlated with the thyroid gland volume as well as with the volume of its left lobe.

Immunosuppressive properties of antithyroid drugs have been observed [54, 55]. Thus, therapeutic MMI action in GD is associated with decreased $\mathrm{TSH}$ receptor antibodies and circulating markers of immune activation [56]. However, due to the absence of any immune markers a direct immunosuppressive effect is considered unlikely by some authors [56]. Our observations clearly indicated that treatment with MMI normalise expression of lymphocyte activation markers and plasma $\mathrm{Mg}$ concentration.

Our results suggest also that severe immune system deregulation in the form of high numbers of activated $\mathrm{T}$ and $\mathrm{B}$ lymphocytes, and low plasma Mg concentration may lead to rapid GD relapse after the treatment. This requires further investigations.

\section{Conclusions}

The present study demonstrates that both activated $\mathrm{T}$ and B cells might play an important role in the pathogenesis of GD. The reduced $\mathrm{Mg}$ plasma concentration in GD could be responsible for the loss of immune tolerance, activation of the immune system and development of autoimmune process in this thyroid disorder. The use of MMI in treatment of hyperthyroidism due to GD leads to an increase of plasma $\mathrm{Mg}$ concentration, so it seems to be one of the indicators of proper GD treatment. Treatment with MMI caused also a relevant decrease of the percentages of analysed activated lymphocyte subsets. Obtained results suggest also that
Fig. 21 A positive correlation between the percentages of CD8+CD69+ cells and serum concentration of FT3 before the treatment in the study group $(r=0.499, p<0.00001)$

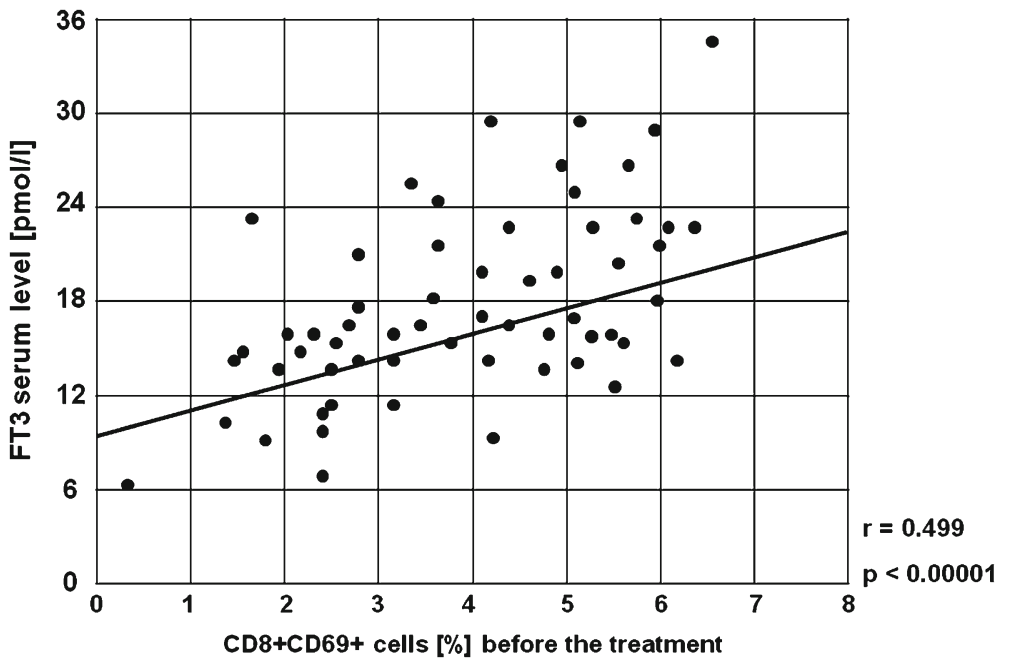


severe immune system deregulation in the form of high numbers of activated cells and low $\mathrm{Mg}$ concentration may lead to rapid GD relapse after the treatment.

Acknowledgments This work was supported by research grant no. N N 402359338 from the Polish State Funds for Scientific Research.

Open Access This article is distributed under the terms of the Creative Commons Attribution License which permits any use, distribution, and reproduction in any medium, provided the original author(s) and the source are credited.

\section{References}

1. Nauman J, Nauman A (1995) Graves disease: etiopathogenesis, clinics, treatment. Polish J Endocrinol 46:3-8

2. Rivkees SA (2006) The treatment of Graves' disease in children. J Pediatr Endocrinol Metab 19:1095-1111

3. Lombardo F, Messina MF, Salzano G, Rabbone I, Lo Presti D, Calcaterra V, Aversa T, De Luca F, Wasniewska M (2011) Prevalence, presentation and clinical evolution of Graves' disease in children and adolescents with type 1 diabetes mellitus. Horm Res Paediatr 76:221-225. doi:10.1159/000327587

4. Mao C, Wang S, Xiao Y, Xu J, Jiang Q, Jin M, Jiang X, Guo H, Ning G, Zhang Y (2011) Impairment of regulatory capacity of $\mathrm{CD} 4+\mathrm{CD} 25+$ regulatory $\mathrm{T}$ cells mediated by dendritic cell polarization and hyperthyroidism in Graves' disease. J Immunol $186: 4734-4743$

5. Heufelder AE, Wenzel BE, Scriba PC (1996) Antigen receptor variable region repertoires expressed by $\mathrm{T}$ cells infiltrating thyroid, retroorbital, and pretibial tissue in Graves' disease. J Clin Endocrinol Metab 81:3733-3739

6. Nakashima M, Martin A, Davies TF (1996) Intrathyroidal T cell accumulation in Graves' disease: delineation of mechanisms based on in situ T cell receptor analysis. Clin Endocrinol Metab 81:3346-3351

7. Ban Y, Davies TF, Greenberg DA, Concepcion ES, Osman R, Oashi T, Tomer Y (2004) Arginine at position 74 of the HLA-DR betal chain is associated with Graves' disease. Genes Immun 5:203-208

8. Lohr J, Knoechel B, Abbas AK (2006) Regulatory T cells in the periphery. Immunol Rev 212:149-162

9. Hegedüs L, Smith TJ, Douglas RS, Nielsen CH (2011) Targeted biological therapies for Graves' disease and thyroid-associated ophthalmopathy. Focus on B-cell depletion with rituximab. Clin Endocrinol (Oxf) 74:1-8. doi:10.1111/j.1365-2265.2010.03806.x

10. Salvi M, Vannucchi G, Campi I, Beck-Peccoz P (2009) Rituximab in the treatment of thyroid eye disease: science fiction? Orbit 28:251-255

11. Dube L, Granry JC (2003) The therapeutic use of magnesium in anaesthesiology, intensive care and emergency medicine: a review. Can J Anesth 50:732-746

12. Desagher S, Martinou JC (2000) Mitochondria as the central control point of apoptosis. Cell Biol 10:369-374

13. Chien MM, Zahradka KE, Newell MK, Freed JH (1999) Fas induced B cell apoptosis requires an increase in free cystolic magnesium as an early event. J Biol Chem 274:7056-7059

14. Wu N, Veillette A (2011) Immunology: magnesium in a signalling role. Nature 7357:462-463. doi:10.1038/475462a

15. Cakmak I, Kirkby EA (2008) Role of magnesium in carbon partitioning and alleviating photooxidative damage. Physiol Plant 133:692-704

16. Cowan JA (2002) Structural and catalytic chemistry of magnesium-dependent enzymes. Biometals 15:225-235
17. Yang W, Lee JY, Nowotny M (2006) Making and breaking nucleic acids: two- $\mathrm{Mg}^{2+}$-ion catalysis and substrate specificity. Mol Cell 22:5-13

18. Li FY, Chaigne-Delalande B, Kanellopoulou C, Davis JC, Matthews HF, Douek DC, Cohen JI, Uzel G, Su HC, Lenardo MJ (2011) Second messenger role for $\mathrm{Mg}^{2+}$ revealed by human Tcell immunodeficiency. Nature 7357:471-476. doi:10.1038/ nature 10246

19. Gasser A, Bruhn S, Guse AH (2006) Second messenger function of nicotinic acid adenine dinucleotide phosphate revealed by an improved enzymatic cycling assay. J Biol Chem 281:16906-16913

20. Murphy E (2000) Mysteries of magnesium homeostasis. Circ Res 86:245-248

21. Permyakov EA, Kretsinger RH (2009) Cell signaling, beyond cytosolic calcium in eukaryotes. J Inorg Biochem 103:77-86

22. Takaya J, Higashino H, Kobayashi Y (2000) Can magnesium act as a second messenger? Current data on translocation induced by various biologically active substances. Magnes Res 13:139-146

23. Pearce SHS (2004) Spontaneous reporting of adverse reactions to carbimazole and propylthiouracil in the UK. Clin Endocrinol 61:589-594

24. Molnar I (2007) The balance shift in Th1/Th2 related IL-12/IL-5 cytokines in Graves' disease during methimazole therapy. Autoimmunity 40:31-37

25. Crescioli C, Cosmi L, Borgogni E, Santarlasci V, Gelmini S, Sottili M, Sarchielli E, Mazzinghi B, Francalanci M, Pezzatini A, Perigli G, Vannelli GB, Annunziato F, Serio M (2007) Methimazole inhibits CXC chemokine ligand 10 secretion in human thyrocytes. J Endocrinol 195:145-155

26. Antonelli A, Rotondi M, Fallahi P, Romagnani P, Ferrari SM, Barani L, Ferrannini E, Serio M (2006) Increase of interferongamma-inducible CXC chemokine CXCL10 serum levels in patients with active Graves' disease, and modulation by methimazole therapy. Clin Endocrinol 64:189-195

27. Sato H, Sasaki N, Minamitani K, Minagawa M, Kazukawa I, Sugihara S, Wataki K, Konda S, Inomata H, Sanayama K, Kohno Y (2012) Higher dose of methimazole causes frequent adverse effects in the management of Graves' disease in children and adolescents. J Pediatr Endocrinol Metab 25:863-867. doi:10.1515/jpem-2012-0138

28. Chakraborty P, Ghosh S, Goswami SK, Kabir SN, Chakravarty B, Jana K (2013) Altered trace mineral milieu might play an aetiological role in the pathogenesis of polycystic ovary syndrome. Biol Trace Elem Res 152:9-15. doi:10.1007/s12011-012-9592-5

29. Yan YQ, Liu XC, Jing WB, Wang Z, Bai XY, Yang Q, He GW (2013) Alteration of plasma trace elements in patients undergoing open heart surgery. Biol Trace Elem Res 151:344-349. doi:10.1007/s12011-012-9577-4

30. Kim YH, Jung KI, Song CH (2012) Effects of serum calcium and magnesium on heart rate variability in adult women. Biol Trace Elem Res 150:116-122. doi:10.1007/s12011-012-9518-2

31. Tarighat Esfanjani A, Mahdavi R, Ebrahimi Mameghani M, Talebi M, Nikniaz Z, Safaiyan A (2012) The effects of magnesium, Lcarnitine, and concurrent magnesium-L-carnitine supplementation in migraine prophylaxis. Biol Trace Elem Res 150:42-48. doi:10.1007/s12011-012-9487-5

32. Rasheed H, Elahi S, Ajaz H (2012) Serum magnesium and atherogenic lipid fractions in type II diabetic patients of Lahore, Pakistan. Biol Trace Elem Res 148:165-169. doi:10.1007/s12011-012-9361-5

33. Vezyraki P, Kalfakakou V, Evangelou A (2000) Atrial natriuretic peptide and thyroid hormones' relation to plasma and heart calcium and magnesium concentrations of Wistar rats exposed to cold and hot ambients. Biol Trace Elem Res 73:163-173

34. Hammerstad SS, Norheim I, Paulsen T, Amlie LM, Eriksen EF (2013) Excessive decrease in serum magnesium after total 
thyroidectomy for Graves' disease is related to development of permanent hypocalcemia. World J Surg 37:369-375. doi:10.1007/s00268-012-1843-2

35. Disashi T, Iwaoka T, Inoue J, Naomi S, Fujimoto Y, Umeda T, Tomita K (1996) Magnesium metabolism in hyperthyroidism. Endocr J 43:397-402

36. Cheng CC, Yang SP, Lin WS, Ho LJ, Lai JH, Cheng SM, Lin WY (2012) Magnesium lithospermate B mediates anti-inflammation targeting activator protein-1 and nuclear factor-kappa B signaling pathways in human peripheral $\mathrm{T}$ lymphocytes. Int Immunopharmacol 13:354-361. doi:10.1016/j.intimp.2012.04.011

37. Wang L, Kang N, Zhou J, Guo Y, Zhang X, Cui L, Ba D, He W (2012) Downregulation of CD94/NKG2A inhibitory receptor on decreased $\gamma \delta \mathrm{T}$ cells in patients with systemic lupus erythematosus. Scand J Immunol 76:62-69. doi:10.1111/j.13653083.2012.02705.x

38. Perniola R, Lobreglio G, Rosatelli MC, Pitotti E, Accogli E, De Rinaldis C (2005) Immunophenotypic characterisation of peripheral blood lymphocytes in autoimmune polyglandular syndrome type 1: clinical study and review of the literature. J Pediatr Endocrinol Metab 18:155-164

39. Song ZY, Liu W, Xue LQ, Pan CM, Wang HN, Gu ZH, Yang SY, Cao HM, Zuo CL, Zhang XN, Jiang H, Liu BL, Bi YX, Zhang XM, Zhao SX, Song HD (2012) Dense mapping of IL2RA shows no association with Graves' disease in Chinese Han population. Clin Endocrinol (Oxf). doi:10.1111/cen.12115

40. Chistiakov DA, Chistiakova EI, Voronova NV, Turakulov RI, Savost'anov KV (2011) A variant of the I12ra/Cd25 gene predisposing to Graves' disease is associated with increased levels of soluble interleukin-2 receptor. Scand J Immunol 74:496-501. doi:10.1111/j.1365-3083.2011.02608.x

41. Brand OJ, Lowe CE, Heward JM, Franklyn JA, Cooper JD, Todd JA, Gough SC (2007) Association of the interleukin-2 receptor alpha (IL-2Ralpha)/CD25 gene region with Graves' disease using a multilocus test and tag SNPs. Clin Endocrinol (Oxf) 66:508-512

42. Takahashi T, Kuniyasu Y, Toda M, Sakaguchi N, Itoh M, Iwata M, Shimizu J, Sakaguchi S (1998) Immunologic self-tolerance maintained by $\mathrm{CD} 25+\mathrm{CD} 4+$ naturally anergic and suppressive $\mathrm{T}$ cells: induction of autoimmune disease by breaking their anergic/ suppressive state. Int Immunol 10:1969-1980

43. Mysliwiec J, Palyga I, Nikolajuk A, Kowalska A, Gorska M (2012) Serum interleukin-16 and RANTES during treatment of Graves' orbitopathy with corticosteroids and teleradiotherapy. Endokrynol Pol 63:92-96

44. Marzio R, Mauël J, Betz-Corradin S (1999) CD69 and regulation of the immune function. Immunopharmacol Immunotoxicol $21: 565-582$
45. Ishikawa C, Mori N (2013) Epstein-Barr virus latent membrane protein 1 induces CD69 expression through activation of nuclear factor-KB. Int J Oncol 42:1786-1792. doi:10.3892/ijo.2013.1871

46. Shinoda K, Tokoyoda K, Hanazawa A, Hayashizaki K, Zehentmeier S, Hosokawa H, Iwamura C, Koseki H, Tumes DJ, Radbruch A, Nakayama T (2012) Type II membrane protein CD69 regulates the formation of resting T-helper memory. Proc Natl Acad Sci U S A 109:7409-7414. doi:10.1073/pnas.1118539109

47. Ishikawa C, Kawakami H, Uchihara JN, Senba M, Mori N (2013) CD69 overexpression by human T-cell leukemia virus type 1 Tax transactivation. Biochim Biophys Acta 1833:1542-1552. doi:10.1016/j.bbamcr.2013.03.006

48. Fornara O, Odeberg J, Khan Z, Stragliotto G, Peredo I, Butler L, Söderberg-Nauclér C (2013) Human cytomegalovirus particles directly suppress CD4 T-lymphocyteactivation and proliferation. Immunobiology. doi:10.1016/j.imbio.2013.01.002

49. Funderburg NT, Sieg SF (2012) Diminished responsiveness to human $\beta$-defensin- 3 and decreased TLR1 expression on monocytes and mDCs from HIV-1-infected patients. J Leukoc Biol 92:1103-1109. doi:10.1189/jlb.1111555

50. Yehudai D, Snir A, Peri R, Halasz K, Haj T, Odeh M, Kessel A (2012) B cell-activating factor enhances interleukin-6 and interleukin-10 production by ODN-activated human B cells. Scand J Immunol 76:371-377. doi:10.1111/j.1365-3083.2012.02752.x

51. Ferraris FK, Moret KH, Figueiredo AB, Penido C, Henriques M (2012) Gedunin, a natural tetranortriterpenoid, modulates T lymphocyte responses and ameliorates allergic inflammation. Int Immunopharmacol 14:82-93. doi:10.1016/j.intimp.2012.06.002

52. Chavez-Rueda K, Legorreta-Haquet MV, Cervera-Castillo $\mathrm{H}$ Sánchez L, Jara LJ, Zenteno E, Blanco-Favela F (2005) Prolactin effect on CD69 and CD154 expression by CD4+ cells from systemic lupus erythematosus patients. Clin Exp Rheumatol 23:769-777

53. Gessl A, Waldhäusl W (1998) Elevated CD69 expression on naive peripheral blood T-cells in hyperthyroid Graves'disease and autoimmune thyroiditis: discordant effect of methimazole on HLA-DR andCD69. Clin Immunol Immunopathol 87:168-175

54. Bandyopadhyay U, Biswas K, Banerjee RK (2002) Extrathyroidal actions of antithyroid thionamides. Toxicol Lett 128:117-127

55. Lechpammer M, Lukac J, Lechpammer S, Kusić Z (2002) Antithyroid drug-induced immunomodulation in Graves' disease patients. Acta Med Croatica 56:21-26

56. Gu X, Zheng L, Chen X, Ruan L, Zhang H, Ge S, Zhu H, Lin X, Shen F (2012) Elevated serum IL-16 and RANTES levels in patients with autoimmune thyroid diseases and modulation by methimazole therapy. Horm Metab Res 44:482-487. doi:10.1055/s0032-1308973 